Cinematic Canines 



\section{Cinematic Canines}

\section{Dogs and Their Work in the Fiction Film}

EDITED BY

ADRIENNE L. MCLEAN

Rutgers University Press 
Library of Congress Cataloging-in-Publication Data

Cinematic canines : dogs and their work in the fiction film / edited by Adrienne L. McLean.

pages $\mathrm{cm}$

Includes bibliographical references and index.

ISBN 978-0-8135-6356-5 (hardcover : alk. paper) - ISBN 978-0-8135-6355-8 (pbk. : alk. paper) - ISBN 978-0-8135-6357-2 (e-book)

I. Dogs in motion pictures. I. McLean, Adrienne L., editor of compilation.

PNi995.9.A5C555 2014

$791.43^{\prime} 662-\mathrm{dc} 23$

2013027193

A British Cataloging-in-Publication record for this book is available from the British Library.

This collection copyright $\left({ }^{\circ} 2014\right.$ by Rutgers, The State University

Individual chapters copyright $\left({ }_{2} 2 \mathrm{I}_{4}\right.$ in the names of their authors

All rights reserved

No part of this book may be reproduced or utilized in any form or by any means, electronic or mechanical, or by any information storage and retrieval system, without written permission from the publisher. Please contact Rutgers University Press, 106 Somerset Street, New Brunswick, NJ ०890I. The only exception to this prohibition is "fair use" as defined by U.S. copyright law.

Visit our website: http://rutgerspress.rutgers.edu

Manufactured in the United States of America 
For Larry and my parents, and all of the dogs who are in this book and those who sat by us while it was written 
